\title{
Pengaruh Media Pembelajaran Game Edukasi Berbasis Construct terhadap Kemampuan Pemecahan Masalah dan Hasil Belajar Siswa
}

\author{
Lia Budi Tristanti1 ${ }^{*}$, Sodi Akbar², dan Widya Ana Rahayu ${ }^{3}$ \\ STKIP PGRI JOMBANG \\ Jalan Pattimura III/20 Jombang \\ $1^{*}$ btlia@rocketmail.com \\ SDN KEPANJEN 2 JOMBANG \\ Jalan Kh Wahid Hasyim 97 \\ ${ }^{2}$ sodiakbar29@gmail.com \\ SMK PGRI 1 JOMBANG \\ Jln. Pattimura V/75 Jombang \\ 3widyanar03@gmail.com
}

Artikel diterima: 07-10-2020, direvisi: 29-01-2021, diterbitkan: 31-01-2021

\begin{abstract}
Abstrak
Tujuan penelitian ini yaitu mendeskripsikan pengaruh media pembelajaran game edukasi berbasis construct terhadap kemampuan pemecahan masalah, dan terhadap hasil belajar logika matematika di SMK PGRI 1 JOMBANG. Siswa yang terlibat sebanyak 31. Metode penelitian menggunakan eksperimen semu. Adapun jenis desain yang digunakan adalah quasi experiment dengan one-group pretest-posttest design. Teknik pemilihan subjek penelitian yang digunakan adalah teknik simple random sampling. Intrumen penelitian berupa tes. Sebelum melaksanakan penelitian ini, media game edukasi berbasis construct ini telah divalidasi dan direvisi sesuai dengan validator Hasil penelitian ini menunjukkan bahwa adanya pengaruh media game edukasi berbasis construct terhadap kemampuan penyelesaian masalah siswa. Selain itu, diperoleh pula ada perbedaan rata-rata antara hasil belajar Pretest dengan Posttest yang artinya ada pengaruh penggunaan media game edukasi berbasis Construct dalam meningkatkan hasil belajar materi logika matematika.

Kata Kunci: Game Edukasi Berbasis Construct, Kemampuan Pemecahan Masalah, Hasil Belajar.

\section{The Effect of Construct -Based Educational Game Learning Media on Student Problem Solving Ability and Learning Outcomes}

Abstract

The purpose of this study is to describe the effect of construct-based educational game learning media on problem-solving abilities, and on the learning outcomes of mathematics logic at SMK PGRI 1 JOMBANG. Students involved were 31. The research method used a quasi-experimental. The type of design used was a quasi experiment with a one-group pretest-posttest design. The research subject selection technique used was simple random sampling technique. The research instrument was a test. Before carrying out this research, this construct-based educational game media has been validated and revised according to the validator. The results of this study indicate that first, there is an effect of construct-based educational game media on students' problem solving abilities. Also, it was concluded that there was an average difference between the pretest and posttest learning outcomes, which meant that there was an effect of using Construct-based educational game media in improving the learning outcomes of students.

Keyword: Construct-Based Educational Games, Problem Solving Ability, Learning Outcomes.
\end{abstract}




\section{Pendahuluan}

Salah satu tujuan pembelajaran matematika dalam kurikulum 2013 yang tertuang dalam Permendikbud No 36 Tahun 2018 dan National Council of Teachers of Mathematics (NCTM, 2000) menekankan pada kemampuan siswa dalam pemecahan masalah. Saat siswa menyelesaikan suatu masalah, maka ia harus memiliki kemampuan argumen (Tristanti, Sutawidjaja, As'ari, Muksar, 2015, 2016, 2017). Hal tersebut sesuai dengan Tristanti (2019) bahwa argumen digunakan untuk menentukan, menghasilkan dan mendukung solusi yang masuk akal dalam menyelesaikan suatu masalah matematika.

Kemampuan pemecahan masalah matematis diperlukan untuk mempelajari setiap materi pelajaran matematika dalam proses penyelesaian masalah untuk memahami konsep dari materi yang diberikan. Rendahnya kemampuan pemecahan masalah matematis peserta didik ini menyebabkan rendahnya hasil belajar (Suryani, Jufri, \& Putri, 2020). Matematika merupakan pelajaran yang sulit baik untuk mengajarkanya maupun mempelajarinya (Cockroft, 1982:68; Sari \& Afriansyah, 2020). Hal tersebut juga dialami dalam proses pembelajaran matematika di kelas XI SMK PGRI 1 Jombang. Pencapaian hasil belajar siswa tidak meningkat secara signifikan dan bahkan cenderung menurun. Berdasarkan hasil observasi didapatkan berbagai alasan yaitu: (1) proses pembelajaran masih berpusat pada guru, dalam proses pembelajaran yang berlangsung siswa hanya mendengar dan memperhatikan guru yang sedang menjelaskan, lalu siswa menyalin apa yang ditulis guru. Akibatnya pembelajaran matematika tidak sesuai dengan kebutuhannya. Ini menyebabkan rendahnya kemampuan pemecahan masalah matematis siswa. (2) Matematika kurang disukai siswa, karena matematika merupakan pelajaran yang dianggap paling sulit dan suasana pembelajaran kurang menyenangkan sehingga siswa kurang semangat dan merasa cepat bosan mengikuti pelajaran. (3) Siswa kelas XI masih terbawa suasana magang, ada siswa yang belum siap untuk belajar, sehingga hasil belajar matematika rendah.

Dalam mengatasi permasalahan yang terjadi pada pembelajaran matematika di kelas XI SMK PGRI 1 Jombang, peneliti menggunakan teknologi yang dikemas dalam pembelajaran game edukasi berbasis construct untuk mendeskripsikan pengaruh media pembelajaran game edukasi berbasis construct terhadap kemampuan pemecahan masalah, dan terhadap hasil belajar logika matematika. Hal tersebut sesuai dengan pendapat Koh; Kin; Wadhwa \& Lim, (2011) dan Siregar, (2017) bahwa game dalam teknologi bermanfaat dalam proses belajar dan mengajar di sekolah. Game berbasis construct sebagai salah satu media yang efektif digunakan untuk siswa, terutama pada mata pelajaran yang sulit, seperti matematika. Game edukasi software 
(perangkat lunak) membantu siswa untuk memahami pelajaran matematika dan dapat meningkatkan kinerja siswa dalam mempelajari matematika (Kodush, Dowker, Heine, Kaufman, Kucian, 2013; Weijer-Bergsma; Kroesbergen; Juliani, S., \& Van Luit, 2016; Hawkins; Collins; Hernan \& Flowers, 2016; Ninaus; Kristian; McMullen \& Moellar, 2017; Vrugte; Jong; Vandercruysse; Wouters; Oostendorp \& Elen, 2017 ).

Cara kerja media pembelajaran game edukasi berbasis Construct yaitu game edukasi ini berbentuk quiz yang berisi pertanyaan dan pilihan jawaban. Dalam pengembangan di awal media pembelajaran ini kami memberikan 10 buah pertanyaan dalam quiz. Game ini dikembangkan menjadi 2 versi yaitu Versi Html5 yang nantinya dapat digunakan pada Laptop/PC dan Versi yang kedua yaitu Versi APK yang dapat digunakan pada smartphone berbasis android. Keunggulan media game edukasi berbasis construct yaitu tools pembuat game berbasis HTML5 yang dikhususkan untuk platform 2D yang dikembangkan oleh Scirra. Construct tidak menggunakan bahasa pemrograman khusus, karena semua perintah yang digunakan pada game diatur dalam even sheet yang terdiri dari event dan action. Construct tidak menggunakan bahasa pemrograman khusus, jadi untuk untuk mengembangkan game dengan construct pengguna tidak perlu mengerti bahasa pemrograman yang rumit dan sulit.
Pada Gambar 1 merupakan media pembelajaran Game Edukasi berbasis construct, peserta didik dihadapkan dengan tampilan menu yang terdiri dari quiz, petunjuk, dan tentang. Tombol quiz berfungsi untuk membawa dalam soal Logika. Tombol petunjuk jika ditekan akan membawa pada tampilan yang berisi petunjuk penggunaan media tersebut. Tombol Tentang jika ditekan akan membawa pengguna pada halaman yang berisi informasi tentang pembuat aplikasi. Soal yang disediakan dalam quiz ini berisi soal materi logika. Pengguna dapat menjawab soal tersebut dengan menekan tombol jawaban. Jawaban yang disediakan terdiri dari 5 pilihan jawaban. Pengguna dapat memilih salah satu yang dianggap merupakan jawaban paling benar. Setiap selesai menekan tombol jawaban yang sudah tersedia maka system akan merekam data soal yang sudah terjawab dan juga benar atau salah jawaban pengguna. Sebelum melaksanakan penelitian ini, media game edukasi berbasis construct ini telah divalidasi dan direvisi sesuai dengan validator.

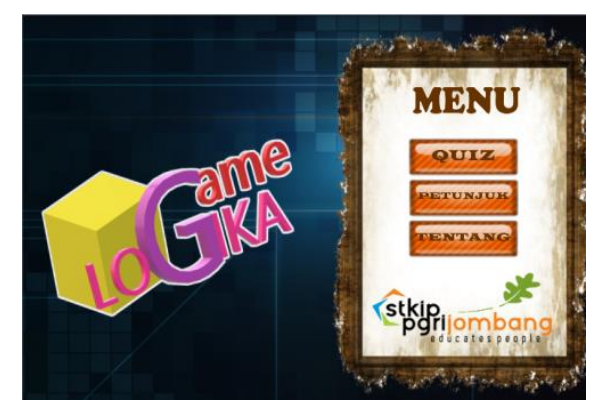




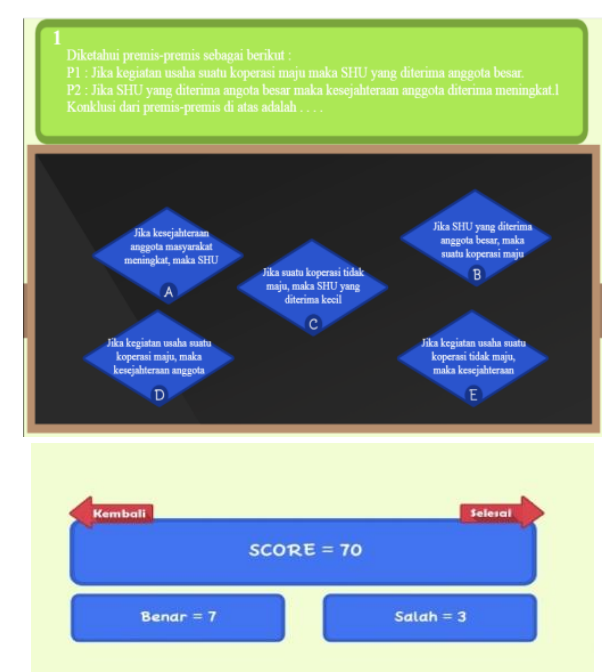

Gambar 1 Tampilan Media Pembelajaran Game Edukasi Berbasis Construct

Dari keterangan di atas menarik bagi peneliti untuk melakukan penelitian, dengan menerapkan pembelajaran menggunakan media game edukasi berbasis construct. Judul penelitian "Pengaruh Media Pembelajaran Game Edukasi Berbasis Construct terhadap Kemampuan Pemecahan Masalah dan Hasil Belajar Logika Matematika Siswa SMK PGRI 1 JOMBANG".

\section{Metode}

Penelitian ini adalah penelitian kuantitatif yang dilakukan di SMK PGRI 1 Jombang. Kelas yang digunakan untuk penelitian adalah XI OTKP 8 dengan subjek penelitian sebanyak 31 siswa. Waktu pelaksanaan penelitian dilakukan pada semester genap tahun pelajaran 2019/2020. Penerapan media contruks ini sebanyak 2 kali pertemuan pada materi logika matematika. Pertemuan pertama yaitu pembelajaran mengenai pembuatan kesimpulan yang valid, dan pertemuan kedua mengenai penentuan nilai variabel pernyataan benar.

Metode yang digunakan dalam penelitian ini adalah metode penelitian eksperimen semu (Quasi experiment). Adapun jenis desain yang digunakan adalah Quasi Experiment dengan one group pretest-posttest design. Kelas tersebut diberikan soal essay berupa soal pretest sebelum penggunaan media dan soal essay posttest setelah penggunaan media.. Teknik pemilihan subjek penelitian yang digunakan adalah teknik simple random sampling.

Kegiatan penelitian ini dilaksanakan pada bulan Juli 2020 pada siswa kelas XI SMK PGRI 1 Jombang semester 2 tahun pelajaran 2019/2020. Proses pembelajaran dilaksanakan di kelas XI OTKP 8 yang terdiri dari 31 siswa. Pelaksanaan pembelajaran berlangsung selama 2 hari, pertemuan 1 berlangsung hari Senin tanggal 6 Juli 2020 dan hari Selasa tanggal 7 Juli 2020 secara daring.

Instrumen yang digunakan dalam penelitian adalah tes kemampuan pemecahan masalah matematika (Pretest dan Posttest). Soal pretest dan posttest tidak sama, namun memuat indikator soal yang sama. Soal pretest dan posttest dalam bentuk essay untuk mengetahui kemampuan pemecahan masalah matematika dan hasil belajar siswa. Hasil dari tes pemecahan masalah memuat beberapa indikator. Adapun indikator pemecahan masalah menurut teori Polya 
(1973) terdapat pada Tabel 1 dan setiap indikator yang terpenuhi diberikan skor untuk data hasil belajar siswa.

Tabel 1

Indikator Pemecahan

\begin{tabular}{|c|c|}
\hline Langkah-langkah & $\begin{array}{l}\text { Indikator } \\
\text { masalah }\end{array}$ \\
\hline \multirow[t]{2}{*}{$\begin{array}{l}\text { Memahami } \\
\text { masalah }\end{array}$} & $\begin{array}{l}\text { 1.1 Menuliskan unsur- } \\
\text { unsur yang diketahui. }\end{array}$ \\
\hline & $\begin{array}{l}\text { 1.2 Menuliskan unsur- } \\
\text { unsur yang ditanya. }\end{array}$ \\
\hline $\begin{array}{l}\text { Merencanakan } \\
\text { pemecahan } \\
\text { masalah }\end{array}$ & $\begin{array}{l}\text { 2.1 } \text { Menjelaskan dengan } \\
\text { rinci beserta alasan } \\
\text { rumus dan operasi } \\
\text { matematika yang akan } \\
\text { digunakan }\end{array}$ \\
\hline $\begin{array}{l}\text { Menyelesaikan } \\
\text { masalah sesuai }\end{array}$ & $\begin{array}{l}\text { 3.1 Menuliskan garis besar } \\
\text { langkah penyelesaian }\end{array}$ \\
\hline rencana & $\begin{array}{l}3.2 \text { Melakukan operasi } \\
\text { hitung. }\end{array}$ \\
\hline $\begin{array}{l}\text { Memeriksa } \\
\text { kembali hasil yang } \\
\text { diperoleh }\end{array}$ & $\begin{array}{l}\text { 4.1 Mengecek kembali } \\
\text { hasil pekerjaan }\end{array}$ \\
\hline
\end{tabular}

Keterangan:

setiap indikator diberi skor

2= Jika semua indikator sudah dipenuhi siswa dengan tepat

1= Jika semua indikator sudah dipenuhi siswa namun belum lengkap

0 = Jika semua indikator belum dipenuhi oleh siswa Adapun hipotesis penelitian ini adalah:

1. HO : tidak ada pengaruh Media Pembelajaran Game Edukasi Berbasis Construct terhadap Kemampuan Pemecahan Masalah Logika Matematika Siswa SMK PGRI 1 JOMBANG $\mathrm{H} 1$ : ada pengaruh Media Pembelajaran Game Edukasi Berbasis Construct terhadap Kemampuan Pemecahan Masalah Logika Matematika Siswa SMK PGRI 1 JOMBANG

2. HO : tidak ada pengaruh Media Pembelajaran Game Edukasi Berbasis Construct terhadap hasil belajar Masalah Logika Matematika Siswa SMK PGRI 1 JOMBANG

$\mathrm{H} 1$ : ada pengaruh Media Pembelajaran Game Edukasi Berbasis Construct terhadap hasil belajar Logika Matematika Siswa SMK PGRI 1 JOMBANG
Data kemampuan pemecahan masalah dianalisis secara kuantitatif dengan menjumlahkan banyak siswa yang memenuhi indicator tahap penyelesaian masalah dan banyak siswa yang tidak memenuhi indikator tersebut. Penerapan media pembelajaran game edukasi berbasis construct berpengaruh terhadap kemampuan pemecahan masalah logika matematika siswa SMK PGRI 1 JOMBANG.

Teknik analisis data hasil belajar siswa menggunakan uji statistik yaitu uji-t. Berikut kriteria penerimaan dan penolakan hipotesis:

1. Jika nilai Sig. (2-tailed)<0,05 maka HO ditolak dan $\mathrm{Ha}$ diterima.

2. Sebaliknya, jika nilai Sig. (2tailed) $>0,05$ maka $\mathrm{HO}$ diterima dan Ha ditolak.

Selain membandingkan antara nilai signifikan (Sig) dengan probabilitas 0,05 ada cara lain yang dapat dilakukan untuk pengujian hipotesis dalam uji paired sample $t$ test. Yakni dengan membandingkan antara nilai $t$ hitung dengan $\mathrm{t}$ table. Adapun pedoman atau dasar pengambilan keputusannya adalah sebagai berikut:

1. Jika nilai t hitung $>\mathrm{t}$ tabel, maka $\mathrm{HO}$ ditolak dan Ha diterima

2. Sebaliknya jika nilai t hitung $<\mathrm{t}$ tabel maka $\mathrm{HO}$ di terima dan $\mathrm{Ha}$ di tolak

Sebelumnya dilakukan uji $t$, terlebih dahulu dilakukan uji prasyarat yaitu normalitas dan homonenitas. Normalitas untuk pengujian terhadap normal atau tidaknya sebaran data yang akan dianalisis. 
Pengujian normalitas sebaran data menggunakan Kolmogorov-Smirnov Test dengan bantuan SPSS 20. Kriteria pengujian adalah sebagai berikut:

1. Jika signifikansi kurang dari 0.05 berarti data yang akan diuji mempunyai perbedaan yang signifikan dengan data normal baku, yang berarti data tersebut tidak normal.

2. Jika signifikansi lebih dari 0.05 maka tidak terdapat perbedaan yang signifikan antara data yang akan diuji dengan data normal baku, yang berarti data tersebut normal

Selanjutnya uji homogenitas menggunakan uji $\mathrm{F}$ dari data pretest dan posttest dengan menggunakan bantuan program SPSS 20. Jika signifikansi yang diperoleh $>\alpha$, berarti kedua kelompok tidak menunjukan perbedaan atau memiliki varians yang sama, sehingga dengan kata lain kedua varians homogen. Sebaliknya Jika signifikansi yang diperoleh $<\alpha$, berarti antara kedua kelompok menunjukan perbedaan atau memiliki varians yang sama atau kedua varians tidak homogen.

\section{Hasil dan Pembahasan}

Sebelum menerapkan media game edukasi berbasis construct, siswa diberikan soal pretest. Selanjutnya adalah pembelajaran matematika menggunakan media game edukasi berbasis construct. Secara umum pada pertemuan pertama dan kedua siswa mengikuti pembelajaran mengenai logika matematika yaitu pembuatan kesimpulan yang valid, dan penentuan nilai variabel pernyataan benar secara E-Learning. Siswa mempelajari materi yang sudah disediakan yang dikirim melalui grup whatsapps. Siswa dipersilahkan untuk mengerjakan soal yang terhubung dengan link game edukasi berbasis construct dengan batasan waktu 20 menit, setelah itu siswa diberikan soal posttest.

Untuk mendapatkan kemampuan penyelesaian masalah dan hasil belajar siswa dalam pembelajaran dengan media game edukasi berbasis construct, dilakukan penilaian terhadap siswa. Instrumen yang digunakan berupa lembar tes pemecahan masalah matematika, yakni terdiri dari 2 soal materi logika matematika. Soal pertama mengenai pembuatan kesimpulan yang valid, dan soal kedua mengenai penentuan nilai variabel pernyataan benar.

Penilaian dilakukan sebanyak 2 kali, sebelum menggunakan media game edukasi berbasis construct dan sesudah menggunakan game edukasi berbasis construct. Skor nilai ditentukan dengan cara membagi skor yang diperoleh dibagi skor maksimum dikalikan 100.

\section{A. Kemampuan Penyelesaian Masalah Matematika}

Berdasarkan Tabel 2 nampak bahwa banyak siswa memenuhi indicator pemecahan masalah semakin bertambah setelah penerapan pembelajaran matematika dengan menggunakan media game edukasi berbasis construct. Hal 


\section{tersebut mengindikasikan bahwa adanya construct terhadap kemampuan pengaruh media game edukasi berbasis penyelesaian masalah siswa siswa.}

Tabel 2

Deskripsi Pemecahan Masalah Matematika Siswa

\begin{tabular}{|c|c|c|c|}
\hline \multirow{2}{*}{$\begin{array}{l}\text { No } \\
\text { Soal }\end{array}$} & \multirow{2}{*}{$\begin{array}{c}\text { Tahap } \\
\text { Pemecahan } \\
\text { Masalah } \\
\text { Matematika }\end{array}$} & \multicolumn{2}{|c|}{ Hasil Tes } \\
\hline & & Pretest & Postest \\
\hline \multirow[t]{3}{*}{1} & $\begin{array}{l}\text { Memahami } \\
\text { masalah }\end{array}$ & $\begin{array}{l}\text { Tahapan ini ada sebanyak } 29 \text { siswa } \\
\text { menuliskan yang diketahui dan } \\
\text { ditanyakan dari soal dengan benar, } \\
\text { dan ada } 2 \text { siwa yang hanya } \\
\text { menuliskan diketahui saja tanpa } \\
\text { menuliskan yang ditanyakan dari } \\
\text { soal. }\end{array}$ & $\begin{array}{l}\text { Tahapan ini ada sebanyak } 29 \text { siswa } \\
\text { menuliskan yang diketahui dan } \\
\text { ditanyakan dari soal dengan benar, } \\
\text { dan ada } 2 \text { siwa yang hanya } \\
\text { menuliskan diketahui saja tanpa } \\
\text { menuliskan yang ditanyakan dari } \\
\text { soal. }\end{array}$ \\
\hline & $\begin{array}{l}\text { Merencanakan } \\
\text { pemecahan } \\
\text { masalah }\end{array}$ & $\begin{array}{l}\text { Tahapan ini ada sebanyak } 17 \text { siswa } \\
\text { menuliskan rumus untuk } \\
\text { memecahkan masalah dengan } \\
\text { tepat, ada } 11 \text { siswa menuliskan } \\
\text { rumus untuk memecahkan masalah } \\
\text { namun belum lengkap, ada } 3 \text { siswa } \\
\text { tidak menuliskan rumus untuk } \\
\text { memecahkan masalah. }\end{array}$ & $\begin{array}{l}\text { Tahapan ini ada sebanyak } 26 \text { siswa } \\
\text { menuliskan rumus untuk } \\
\text { memecahkan masalah dengan } \\
\text { tepat, ada } 3 \text { siswa menuliskan } \\
\text { rumus untuk memecahkan masalah } \\
\text { namun belum lengkap, ada } 2 \text { siswa } \\
\text { tidak menuliskan rumus untuk } \\
\text { memecahkan masalah. }\end{array}$ \\
\hline & $\begin{array}{l}\text { Menyelesaikan } \\
\text { masalah sesuai } \\
\text { rencana }\end{array}$ & $\begin{array}{l}\text { Tahapan ini ada sebanyak } 1 \text { siswa } \\
\text { menuliskan garis besar langkah } \\
\text { penyelesaian dan membuat } \\
\text { jawaban dengan perhitungan yang } \\
\text { tepat, ada } 5 \text { siswa yang menuliskan } \\
\text { garis besar langkah penyelesaian } \\
\text { dan membuat jawaban dengan } \\
\text { perhitungan yang belum lengkap, } \\
\text { ada } 25 \text { siswa yang tidak menuliskan } \\
\text { garis besar langkah penyelesaian } \\
\text { dan jawaban. }\end{array}$ & $\begin{array}{l}\text { Tahapan ini ada sebanyak } 20 \text { siswa } \\
\text { menuliskan garis besar langkah } \\
\text { penyelesaian dan membuat } \\
\text { jawaban dengan perhitungan yang } \\
\text { tepat, ada } 3 \text { siswa yang menuliskan } \\
\text { garis besar langkah penyelesaian } \\
\text { dan membuat jawaban dengan } \\
\text { perhitungan yang belum lengkap, } \\
\text { ada } 8 \text { siswa yang tidak menuliskan } \\
\text { garis besar langkah penyelesaian } \\
\text { dan jawaban. }\end{array}$ \\
\hline \multirow[t]{2}{*}{2} & $\begin{array}{l}\text { Memahami } \\
\text { masalah }\end{array}$ & $\begin{array}{l}\text { Tahapan ini ada sebanyak } 22 \text { siswa } \\
\text { menuliskan yang diketahui dan } \\
\text { ditanyakan dari soal dengan benar, } \\
\text { dan ada } 9 \text { siwa yang hanya } \\
\text { menuliskan diketahui saja tanpa } \\
\text { menuliskan yang ditanyakan dari } \\
\text { soal. }\end{array}$ & $\begin{array}{l}\text { Tahapan ini ada sebanyak } 27 \text { siswa } \\
\text { menuliskan yang diketahui dan } \\
\text { ditanyakan dari soal dengan benar, } \\
\text { dan ada } 4 \text { siwa yang hanya } \\
\text { menuliskan diketahui saja tanpa } \\
\text { menuliskan yang ditanyakan dari } \\
\text { soal. }\end{array}$ \\
\hline & $\begin{array}{l}\text { Merencanakan } \\
\text { pemecahan } \\
\text { masalah }\end{array}$ & $\begin{array}{l}\text { Tahapan ini ada sebanyak } 8 \text { siswa } \\
\text { menuliskan rumus untuk } \\
\text { memecahkan masalah dengan } \\
\text { tepat, ada } 19 \text { siswa menuliskan } \\
\text { rumus untuk memecahkan masalah } \\
\text { namun belum lengkap, ada } 4 \text { siswa } \\
\text { tidak menuliskan rumus untuk } \\
\text { memecahkan masalah. }\end{array}$ & $\begin{array}{l}\text { Tahapan ini ada sebanyak } 21 \text { siswa } \\
\text { menuliskan rumus untuk } \\
\text { memecahkan masalah dengan } \\
\text { tepat, ada } 10 \text { siswa menuliskan } \\
\text { rumus untuk memecahkan masalah } \\
\text { namun belum lengkap. }\end{array}$ \\
\hline
\end{tabular}


Menyelesaikan masalah sesuai rencana
Tahapan ini ada sebanyak 1 siswa memasukkan data sesuai langkah penyelesaian dan membuat jawaban dengan perhitungan yang tepat, ada 5 siswa yang menuliskan garis besar langkah penyelesaian dan membuat jawaban dengan perhitungan yang belum lengkap, ada 25 siswa yang tidak menuliskan garis besar langkah penyelesaian dan jawaban.
Tahapan ini ada sebanyak 13 siswa memasukkan data sesuai langkah penyelesaian dan membuat jawaban dengan perhitungan yang tepat, ada 15 siswa yang menuliskan garis besar langkah penyelesaian dan membuat jawaban dengan perhitungan yang belum lengkap, ada 3 siswa yang tidak menuliskan garis besar langkah penyelesaian dan jawaban.

\section{B. Hasil Belajar}

Lembar jawaban siswa pada tes kemampuan pemecahan masalah diberikan nilai untuk data hasil belajar

Tabel 3

Hasil Output SPSS Uji Normalitas

\begin{tabular}{|c|c|c|c|}
\hline & & Pretest & Postest \\
\hline \multicolumn{2}{|l|}{$\mathrm{N}$} & 31 & 31 \\
\hline \multirow{4}{*}{$\begin{array}{l}\text { Normal } \\
\text { Parametersa,b }\end{array}$} & Mean & 54,0332 & 84,677 \\
\hline & & & 7 \\
\hline & Std. Deviation & 13,58724 & 11,998 \\
\hline & & & 18 \\
\hline \multirow{3}{*}{$\begin{array}{l}\text { Most Extreme } \\
\text { Differences }\end{array}$} & Absolute & 211 & 157 \\
\hline & Positive & ,165 & ,145 \\
\hline & Negative &,- 211 &,- 157 \\
\hline \multicolumn{2}{|l|}{ Test Statistic } & ,211 & 157 \\
\hline \multicolumn{2}{|c|}{ Asymp. Sig. (2-tailed) } & ,001c & ,049c \\
\hline
\end{tabular}

a. Test distribution is Normal.

b. Calculated from data.

c. Lilliefors Significance Correction. sebagaimana Tabel 1. Berikut analisis hasil belajar siswa

1) Uji Normalitas 


\begin{tabular}{|llrr|}
\hline N & & 31 & 31 \\
\hline Normal Parametersa,b & Mean & 7,3969 & 4,4289 \\
\cline { 2 - 4 } & Std. Deviation &, 98093 &, 14442 \\
\hline Most Extreme Differences & Absolute &, 154 &, 151 \\
\cline { 2 - 4 } & Positive &, 154 &, 135 \\
\cline { 2 - 4 } & Negative &,- 138 &,- 151 \\
\hline Test Statistic & &, 154 &, 151 \\
\hline Asymp. Sig. (2-tailed) & &, $059 c$ &, $069 c$ \\
\hline
\end{tabular}

a. Test distribution is Normal.

b. Calculated from data.

c. Lilliefors Significance Correction.

Berdasarkan Uji Kolmogorov-Smirnov pada variabel residual diatas, nilai signifikansi dari variabel Pre Test dan Post Test nilainya lebih dari 0.05. Pada variabel Pre Test sebesar 0,059 dan pada variabel Post Test sebesar 0,069, maka data-data tersebut terdistribusi normal.

2) Uji Homogenitas

Uji homogenitas menggunakan uji $F$ dari data pretest dan posttest dengan menggunakan bantuan program SPSS 20. Jika signifikansi yang diperoleh $>\alpha$, berarti kedua kelompok tidak menunjukan perbedaan atau memiliki varians yang sama, sehingga dengan kata lain kedua varians homogen. Sebaliknya Jika signifikansi yang diperoleh $<\alpha$, berarti antara kedua kelompok menunjukan perbedaan atau memiliki varians yang sama atau kedua varians tidak homogen.

Tabel 5.

Hasil Uji Homogenitas

\begin{tabular}{cccc}
\hline $\begin{array}{c}\text { Levene } \\
\text { Statistic }\end{array}$ & df1 & df2 & Sig. \\
\hline
\end{tabular}
1,332
1
60
, 253

Berdasarkan Uji F pada Tabel 5, nilai signifikansi yang diperoleh $>\alpha$ yaitu 0,253 yang berarti signifikansi lebih dari $\alpha$, berarti kedua kelompok Pre Test dan Post Test tidak menunjukan perbedaan atau memiliki varians yang sama, sehingga dengan kata lain kedua varians homogen.

3) Uji Paired Sample T-Test

Tabel 6

Hasil Perhitungan Korelasi

\begin{tabular}{rrrrr}
\hline & $\mathrm{N}$ & Correlation & Sig. \\
\hline Pair 1 & $X \& Y$ & 31 &, 626 &, 000
\end{tabular}

Berdasarkan Tabel 6 menunjukkan hasil uji korelasi atau hubungan antara variabel Pre-test dan Post-test. Berdasarkan tabel terebut, diketahui nilai korelasi sebesar 0,626 dengan nilai signifikansi sebesar 0,000 . Karena nilai signifikansi $0,000<\alpha$ $(0,05)$ maka dapat dikatakan bahwa terdapat hubungan antara variabel Pretest dan Post-test.

\section{Tabel 7}

Hasil Perhitungan Uji T

Paired Samples Test 


\begin{tabular}{|c|c|c|c|c|c|c|c|c|c|}
\hline & & \multirow[t]{2}{*}{ Mean } & \multirow[t]{2}{*}{$\begin{array}{c}\text { Std. } \\
\text { Deviati } \\
\text { on }\end{array}$} & \multirow[t]{2}{*}{$\begin{array}{l}\text { Std. } \\
\text { Error } \\
\text { Mean }\end{array}$} & \multicolumn{2}{|c|}{$\begin{array}{l}\text { 95\% Confidence } \\
\text { Interval of the } \\
\text { Difference }\end{array}$} & & & \multirow[t]{2}{*}{$\begin{array}{c}(2- \\
\text { tailed) }\end{array}$} \\
\hline & & & & & Lower & Upper & & & \\
\hline Pair 1 & $X-Y$ & 2,9680 & 89768 & ,16123 & 2,63873 & 3,29727 & 18,409 & 30 & ,000 \\
\hline
\end{tabular}

Berdasarkan Tabel 7, dapat diketahui nilai signifikansi untuk sebesar 0,000 < 0,05 dan nilai t hitung 18,409 > t tabel 2,045, sehingga dapat disimpulkan bahwa $\mathrm{HO}$ ditolak dan $\mathrm{Ha}$ diterima yang berarti terdapat pengaruh perbedaan rata-rata antara hasil belajar Pre Test dan Post Test yang artinya ada pengaruh penggunaan media game edukasi berbasis construct terhadap hasil belajar materi logika matematika siswa kelas XI OTKP 8 SMK PGRI 1 Jombang.

Hasil penelitian ini menunjukkan bahwa adanya pengaruh media pembelajaran game edukasi berbasis construct terhadap kemampuan pemecahan masalah. Hal tersebut mengindikasikan bahwa media pembelajaran berperan dalam mengembangkan kemampuan pemecahan masalah siswa sebagaimana hasil penelitian Purwandari, Ekawati dan Tristanti (2020).

Hasil penelitian ini menunjukkan bahwa adanya pengaruh media pembelajaran game edukasi berbasis construct terhadap hasil belajar siswa meskipun materi ajar yang rumit. Kerumitan materi ajar yang akan disampaikan pada anak didik dapat disederhanakan dengan bantuan media pembelajaran sehingga peserta didik dapat lebih cepat dalam memahami materi ajar (Batubara, 2015).

\section{Penutup}

Berdasarkan hasi penelitian dapat disimpulkan bahwa saat posttes jumlah siswa yang memenuhi indikator pemecahan masalah lebih banyak dari pretest. Dengan kata lain bahwa setelah penerapan game edukasi berbasis construct, jumlah siswa yang memenuhi indikator pemecahan masalah lebih banyak. Hal tersebut menunjukkan bahwa ada pengaruh Media Pembelajaran Game Edukasi Berbasis Construct terhadap Kemampuan Pemecahan Masalah Logika Matematika Siswa SMK PGRI 1 JOMBANG.

Nilai sig sebesar $0.00<0.05$, maka ada perbedaan rata-rata antara hasil belajar Pretest dengan Posttest yang artinya ada pengaruh penggunaan media game edukasi berbasis Construct dalam meningkatkan hasil belajar materi logika matematika siswa kelas XI OTKP 8 SMK PGRI 1 Jombang.

Berdasarkan hasil penelitian dapat disarankan bahwa Penerapan model pembelajaran media game edukasi berbasis construct dapat dijadikan salah satu alternatif untuk meningkatkan kemampuan menyelesaikan masalah dan 
hasil belajar matematika siswa dengan menyesuaikan materi yang akan disampaikan.

\section{Daftar Pustaka}

Batubara, H. H. (2015). Pengembangan Media Pembelajaran Interaktif pada Materi Operasi Bilangan Bulat. MUALLIMUNA: Jurnal Madrasah Ibtidaiyah, 1(1), 1-12.

Cockcroft, W. H. (1982). Mathematics Counts: Report of the Committee of Inquiry into the Teaching of Mathematics in Schools under the Chairmanship of $\mathrm{Dr}$ WH Cockcroft. London: Her Majesty's Stationery Office.

Hawkins, R. O., Collins, T., Herman, C. \& Flowers, E. (2017). Using Computer Assisted Instruction to Build Math Fact Fluency: An Implementation Guide. Intervention in School Clinic, 52, 141147.

Kodush, R. C., Dowker, A., Heine, A., Kaufman, L., Kucian, K. (2013). Interventions for improving numerical abilities present and future. Trends in neuroscience and education, 2(2), 85 93.

Koh, E., Kin, Y. G., Wadhwa, B., \& Lim, J. (2011). Teacher perception of games in Singapore School. Simulation \& Gaming, 43.

NCTM. (2000). Principles and Standards for School Mathematics. USA: The National Council of Teacher Mathematics inc.
Ninaus, M., Kristian, K., McMullen, J., \& Moellar, K. (2017). Assesing fraction knowledge by a digital game. Computer and human behavior, 70, 197-206.

Purwandari, I., Ekawati, W., \& Tristanti, L. B. (2020). Penerapan Model Pembelajaran Problem Based Learning Dengan Media Komat Terhadap Pemecahan Masalah Dan Kecemasan Matematika Siswa. Jurnal THEOREMS (The Original Research of Mathematics), 5(1), 1-12.

Polya, G. (1973). How to Solve It. Princeton, New Jersey: Princeton University Press.

Sari, H. M., \& Afriansyah, E. A. (2020). Analisis Miskonsepsi Siswa SMP pada Materi Operasi Hitung Bentuk Aljabar. Mosharafa: Jurnal Pendidikan Matematika, 9(3), 439-450.

Siregar, N. R., (2017). Perspektif guru sekolah dasar pada performansi matematika siswa. Laporan penelitian (tidak diterbitkan). Kendari. Universitas Halu Oleo.

Suliyanto. (2011). Ekonometrika Terapan: Teori Dan Aplikasi Dengan SPSS. Edisi 1. Yogyakarta: ANDI Yogyakarta.

Suryani, M., Jufri, L. H., \& Putri, T. A. (2020). Analisis Kemampuan Pemecahan Masalah Siswa Berdasarkan Kemampuan Awal Matematika. Mosharafa: Jurnal Pendidikan Matematika,9(1), 119130. 
Tristanti, L. B., Sutawidjaja, A., As'ari, A.R., \& Muksar, M. (2015). Modelling Student Mathematical Argumentation with Structural-Intuitive and Deductive Warrant to Solve Mathematics Problem. Proceeding of ICERD.

Tristanti, L. B., Sutawidjaja, A., As'ari, A.R., \& Muksar, M. (2016). The Construct ion of Deductive Warrant Derived from Inductive Warrant in PreserviceTeacher

Mathematical Argumentations.

Tristanti, L. B., Sutawidjaja, A., As'ari, A.R., \& Muksar, M. (2017). Types of Warrant in Mathematical Argumentations of ProspectiveTeacher. International Journal of Science and Engineering Investigations.

Tristanti, L. B. (2019). The process of thinking by prospective teachers of mathematics in making argument. Journal of Education and Learning (EduLearn).

Vrugte, J ter., Jong, T de., Vandercruysse, S., Wouters, P., Oostendorp, H van., \& Elen, J. (2017). Computer game based mathematics education: embedded faded worked example facilitates knowledge acquisition. Learning and instruction, 50, 44- 53.

Weijer-Bergsma, E. V de., Kroesbergen, E. H., Juliani, S., \& Van Luit, J. E. H. (2016). The Monkey Game: A Computerized Verbal Working Memory Task for Self-Reliant
Administration in Primary School Children. Behavior Research Methods, 48(2), 756-771.

\section{Riwayat Hidup Penulis \\ Dr. Lia Budi Tristanti, M.Pd.}

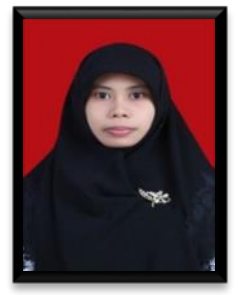

Lahir di Jombang, 27 Oktober 1987. Staf pengajar di STKIP PGRI Jombang. S1 Pendidikan Matematika di STKIP PGRI Jombang, lulus tahun 2010; S2 Pendidikan Matematika di Universitas Negeri Surabaya, lulus tahun 2012; S3 Pendidikan Matematika di Universitas Negeri Malang, lulus tahun 2017.

\section{Sodi Akbar, S.Pd.}

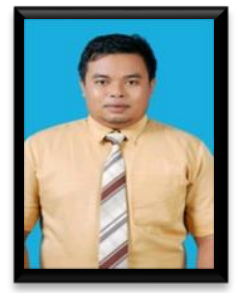

Lahir di Situbondo, 29 Maret 1985. Staf pengajar di SD Negeri Kepanjen 2 Jombang. S1 PGSD di Universitas Terbuka, lulus tahun 2014; S2 pendidikan di Sekolah Tinggi Keguruan dan Ilmu Pendidikan (STKIP) Jombang, sampai dengan sekarang.

Widya Ana Rahayu, S.Si.

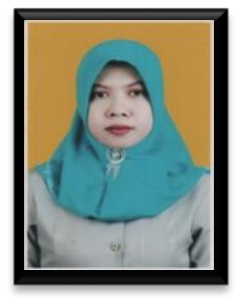

Lahir di Jombang, 3 September 1982. Staf pengajar di SMK PGRI 1 Jombang. S1 pendidikan matematika di Universitas Negeri Surabaya (UNESA), lulus tahun 2004. S2 pendidikan di Sekolah Tinggi Keguruan dan Ilmu Pendidikan (STKIP) Jombang, sampai dengan sekarang. 